\title{
Żegluga śródlądowa w Królestwie Polskim (1815-1830) a polityka gospodarcza ministra skarbu, księcia Franciszka Ksawerego Druckiego-Lubeckiego
}

Karol Karczyński | Wydział Historyczny Uniwersytetu Gdańskiego

\section{Słowa kluczowe \\ gospodarka, transport rzeczny, Królestwo Polskie 1815-1830, Królestwo Kongresowe, Drucki-Lubecki}

Keywords: economy, waterway transport, Kingdom of Poland 1815-1830 Congress Poland Drucki-Lubecki

\section{Streszczenie}

Celem tekstu jest zaprezentowanie najważniejszych działań księcia Franciszka Ksawerego Druckiego-Lubeckiego w latach 1821-1830, zmierzających do rozwoju transportu rzecznego w Królestwie Polskim, które było wówczas w unii personalnej z Rosją. W artykule opisano kwestie takie, jak negocjacje Lubeckiego z rządem pruskim dotyczące taryfy celnej oraz niektóre z pomysłów księcia na zacieśnienie regionalnej współpracy z Cesarstwem Rosyjskim (np. użycie lekkich wozów - kibitek - do stworzenia alternatywy dla handlu wiślanego czy też budowa Kanału Augustowskiego). Poruszono też kwestię roli transportu wodnego w procesie uprzemysłowienia oraz jego znaczenia w handlu solą na terenie Królestwa Polskiego. Podstawowym źródłem informacji wykorzystanych w tekście jest korespondencja między Druckim-Lubeckim a ministrami sekretarzami stanu w Petersburgu. Fakt, że książę Drucki-Lubecki pisał w swoich listach o wyżej wspomnianych projektach, świadczy o ich ważnej roli w ogólnym programie rozwoju gospodarczego Królestwa Polskiego.

Inland navigation in the Kingdom of Poland 1815-1830, and economic policy of Minister of the Treasury, prince Franciszek Ksawery Drucki-Lubecki

\section{Abstract}

The purpose of this research is presenting main actions undertaken over the period 1821-1830 by prince Xawery Drucki-Lubecki to develop inland waterway transport of the Kingdom of Poland staying in a personal union with Russian Empire. This has been done by examining questions such as Lubecki's negotiations with prussian government concerning a tariff, and some of his ideas designed to pull together a regional cooperation with the Russian Empire (an alternative way of transport by means of light wagons and construction of the Augustów Canal). Another question mentioned in the research is the role of a waterway transport in the industrialisation process and in the salt trade in the Kingdom of Poland. A primary source of information used for the purpose of the research was the voluminous correspondence between Drucki-Lubecki and minister secretary state in Petersburg. Fact, that prince Drucki-Lubecki mentioned some of his aforesaid projects in his letters, shows their importance in the general plan of economic development of the Kingdom of Poland. 


\section{Wstęp}

W tekście zaprezentowano wybrane wątki związane z transportem wodnym poruszane przez księcia Franciszka Ksawerego Druckiego-Lubeckiego w korespondencji z ministrami sekretarzami stanu Ignacym Sobolewskim i Stefanem Grabowskim w latach 1821-1830 (Drucki-Lubecki 1909a; 1909b; 1909c; 1909d). Ministrowie ci przebywali stale na dworze carskim w Petersburgu. W pracy omówiono następujące problemy: rolę transportu wodnego w programie ekonomicznym Lubeckiego; kwestie związane z budową Kanału Augustowskiego; rolę dróg wodnych w planie rozwoju górnictwa i przemysłu w woj. sandomierskim (tzw. Staropolskim Okręgu Przemysłowym) oraz wybrane aspekty transportu soli w Królestwie Polskim ze szczególnym uwzględnieniem roli Druckiego-Lubeckiego w zainicjowaniu żeglugi parowej na Wiśle. Ze względu na przejrzystość wywodu daty dzienne w tekście podawane są według obowiązującego w Królestwie Polskim kalendarza gregoriańskiego, nie zaś według kalendarza juliańskiego obowiązującego wówczas w Rosji. Wydaje się to słuszne, ponieważ - chociaż listy i protokoły Rady Administracyjnej Królestwa Polskiego datowane są podwójnie - książę i ministrowie w ich treści posługują się rachubą gregoriańską, podobnie jak większość państw europejskich w owym czasie.

Książę Franciszek Ksawery Drucki-Lubecki sprawował urząd ministra skarbu Królestwa Polskiego w latach 1821-1830. Jako jedyny z ministrów Królestwa Polskiego utrzymywał regularny kontakt z carem Rosji (konstytucyjnym królem polskim) za pośrednictwem stale przebywającego w Petersburgu ministra sekretarza stanu. Od objęcia urzędu do 1823 r. pisał do Ignacego Sobolewskiego, od tego roku zaś do końca swojego urzędowania korespondował ze Stanisławem Grabowskim i jego zastępcą Ignacym Turkułłem. Władcami, z którymi kontaktował się Lubecki, byli w owym czasie Aleksander I (król polski od 3 maja 1815 r. do śmierci 1 grudnia 1825 r.) i Mikołaj I (król polski od 1 grudnia 1825 r. do detronizacji przez sejm Królestwa 25 stycznia 1831 r.).

Lubecki pisał w tym okresie listy co tydzień: po polsku - poufne, z reguły niszczone natychmiast po przeczytaniu przez adresata oraz w języku francuskim, przeznaczone do odczytania w całości lub ustnego zreferowania carowi. W czasie współpracy z Grabowskim ukształtował się i utrzymał do 1830 r. zwyczaj cotygodniowego odczytywania listu Lubeckiego w czasie audiencji ministra sekretarza stanu Królestwa wyznaczonej na wtorek (Drucki-Lubecki 1909a: XXX, XXXIII, XXXIV, XLIII-XLV).

Zakres tematyczny korespondencji Lubeckiego znacznie wykraczał poza sprawy ściśle związane z finansami i obejmował kwestie polityki zagranicznej i wewnętrznej Królestwa oraz jego gospodarki, przemysłu i handlu. W listach i dołączanych do nich memoriałach Lubecki raportował o politycznej i gospodarczej sytuacji Królestwa Polskiego, przekazywał informacje o kluczowych wydarzeniach, przedstawiał swoje projekty i plany działania. Czynił tak ponieważ, przeprowadzając dowolny projekt przez Radę Administracyjną Królestwa Polskiego, nie mógłby liczyć na przychylność senatora Mikołaja Nowosilcowa, specjalnego wysłannika i pełnomocnika cara, który de facto 
kontrolował (niezgodnie z konstytucją Królestwa) ten organ władzy. W tej sytuacji Lubecki wolał działać zakulisowo i omijając Radę odwoływał się do woli cara za pośrednictwem jego ministra - sekretarza stanu (Smolka 1907b: 397).

Jak wynika z powyższego zestawienia, korespondencja Lubeckiego stanowi cenne źródło informacji o wielu aspektach polityki i gospodarki Królestwa Polskiego epoki konstytucyjnej. Została ona przygotowana do druku przez Stanisława Smolkę i wydana w 1909 r. nakładem Akademii Umiejętności (Drucki-Lubecki 1909a: XXIV-XXV).

W korespondencji Lubeckiego znajdują się koncepcje i dość ogólnikowe opisy projektów. Listy nie zawierają szczegółów technicznych, które - choć książę-minister był nimi żywo zainteresowany (Drucki-Lubecki 1909b: 163-164) - nie mogły być zaprezentowane w krótkim czasie przeznaczonym na wtorkową audiencję. Ograniczone miejsce i specyficzna funkcja korespondencji wymuszała na autorze listów nie tylko zwięzłość, ale i wielką ostrożność sformułowań, ponieważ listy były przeglądane przez tajnych współpracowników wielkiego księcia Konstantego i senatora Mikołaja Nowosilcowa, wrogo nastawionych do Lubeckiego. Z tego procederu książę-minister doskonale zdawał sobie sprawę (Drucki-Lubecki 1909a: LII-LIII).

Głównym dążeniem Lubeckiego stało się utrzymanie odrębności państwowej Królestwa Polskiego pozostającego w unii personalnej z Rosją, natomiast wyżej wymienieni jego przeciwnicy polityczni dokładali starań, by odrębność Królestwa podważyć i zlikwidować. Książę stawiał na Rosję jako gwaranta bytu Królestwa, dostrzegając również szanse płynące z takiej sytuacji, jak np. dostęp do rosyjskiego rynku zbytu („2/3 dochodu skarbu" - pisał Lubecki 14 marca 1823 r. - „pochodziło z handlu z Rosją") czy możliwość sięgnięcia do rosyjskiego kapitału w przypadku większych przedsięwzięć gospodarczych planowanych na terenie Królestwa (Drucki-Lubecki 1909a: 194, 350; Zdzitowiecki 1948: 336).

Bez zdobycia i utwierdzenia finansowej niezależności nie można było marzyć o niezależnym Królestwie w unii z potężnym cesarstwem, a jedyną drogą prowadzącą do zwiększenia wpływów do skarbu państwa był rozwój gospodarki kraju. Nie sposób jednak było tego dokonać (podobnie jak dziś) bez sprawnie działającej infrastruktury transportowej, w tym transportu wodnego, stąd też ta problematyka wielokrotnie pojawiała się w korespondencji księcia-ministra z ministrami sekretarzami stanu (Zdzitowiecki 1948: 339-340, 350). Według sławnego i często cytowanego powiedzenia ministra kluczowe znaczenie dla zabezpieczenia odrębności państwowej Królestwa w unii z Rosją miały "fabryki broni, edukacja, bogactwo", a trudno było pomnażać bogactwo bez dobrze funkcjonującej sieci transportowej. W obliczu fatalnego stanu dróg nie sposób było wywozić z Polski towarów ani wwozić ich do niej bez sprawnie funkcjonującego transportu wodnego (Smolka 1907a: 23-24; Szczepański 2008: 136-140; Strzeszewski 1934: 139; Strzeszewski 1937: 26-27).

Podobnie jak w przypadku innych inicjatyw, rozwój transportu Lubecki widział jako środek prowadzący do celu, nie cel sam w sobie. Lubeckiego w żadnym wypadku 
nie można określić mianem ekonomicznego doktrynera. Sam mówił o sobie: „cudów robić nie umiem, szczególnych wiadomości nie posiadam; cała moja nauka gorliwość, trochę zdrowego rozsądku i nieco uporu, a jeśli Król mnie nieco wspierać będzie, jak to dotąd czynił, to będzie miał w rezultacie, co szuka, to jest: że dochody będą przenosić wydatki" (Strzeszewski 1934: 136-140; Zdzitowiecki 1948: 469; Strzeszewski 1937: 62-63).

Impulsem do rozwoju gospodarczego, zwłaszcza przemysłu, według Lubeckiego było stanowisko rządu, gdyż "cel ten może być osiągnięty, bez wątpienia, tylko dzięki wielkim wysiłkom, wielkiemu poświęceniu, i pod dobroczynnym wpływem silnego i sprawnego rządu". Dopiero później postęp techniczny i gospodarczy miał dokonywać się samorzutnie (Drucki-Lubecki 1909b: 69, 288-289). Inicjatywa prywatna miała odegrać swoją rolę w szukaniu i rozpowszechnianiu ulepszeń oraz w obniżaniu kosztów poszczególnych działań.

Lubecki rozróżniał i inaczej traktował handel produktami rolnymi (objets de première nécessité) i przemysłowymi (objets de luxe). By przynosić korzyść Polsce, wywóz tych pierwszych i obrót nimi powinien być maksymalnie wolny, natomiast przywóz drugich powinien być ograniczony tak, aby chronić rodzimą wytwórczość i handel (Drucki-Lubecki 1909b: 236-239). Stosowanie polityki protekcyjnej również było przez Lubeckiego starannie przemyślane i dostosowane do sytuacji; rozsądek inaczej nakazywał postępować wobec Anglii i jej strategii odnośnie do rynku zbożowego, inaczej wobec Prus i ich prężnie działających manufaktur. W pierwszym przypadku maksymalne uwolnienie rynku było korzystne dla Królestwa, w drugim - w interesie Polski leżato konsekwentne utrzymywanie protekcyjnej taryfy celnej dla ochrony dopiero raczkującego przemysłu krajowego. Atutem, z którego warto było skorzystać, była unia z Rosją - państwem stanowiącym potężny rynek zbytu. Zdaniem Lubeckiego należało dążyć do otwarcia jej granic dla wyrobów polskiego przemysłu (Drucki-Lubecki 1909a: 14, 138-143, 384-387; Drucki-Lubecki 1909b: 47-50, 117-118; Szczepański 2008: 146; Zdzitowiecki 1948: 338-339).

Lubecki dobrze rozumiał rolę transportu jako krwiobiegu państwa. Tylko rozbudowana i sprawnie działająca sieć komunikacyjna umożliwiała pomnażanie bogactwa, cyrkulację pieniądza i aktywizację gospodarczą peryferyjnych obszarów kraju. Rola dróg wodnych w czasach przed pojawieniem się na ziemiach polskich kolei była szczególnie doniosła, spełniały one bowiem wiele różnorodnych i wzajemnie niewykluczających się funkcji. Po pierwsze, stanowiły podstawę aktywności przemysłowej jako źródło energii i droga transportu surowców i wyrobów, po drugie zaś stymulowały handel wewnętrzny i zagraniczny, ponieważ umożliwiały stosunkowo tani i szybki przywóz oraz wywóz tzw. towarów masowych?'.

1 Przewóz jednej tony na początku lat 40. XIX w. drogą wodną był pięciokrotnie tańszy niż przewiezienie tej samej ilości towaru lądem (Jezierski, Zawadzki 1966: 66). 
Różne aspekty transportu wodnego poruszał list Lubeckiego z 3 listopada $1826 \mathrm{r}$. Książę-minister zaproponował w nim przekopanie kanału łączącego Narew z Wisłą w okolicach Pragi (a zatem trasę dzisiejszego Kanału Żerańskiego), skracając tym samym drogę w kierunku Bugu oraz - poprzez projektowany również przez księcia Kanał Augustowski - otwierając możliwość żeglugi Niemnem do Bałtyku z pominięciem Prus, co stanowiłoby impuls do rozwoju handlu między Królestwem a resztą Imperium. Lubecki szacował koszt inwestycji w przybliżeniu na $2 \mathrm{mln}$ zł, wliczając $w$ to odszkodowania dla właścicieli terenu. Kanał nie został jednak zbudowany (Drucki-Lubecki 1909b: 340-343; Drucki-Lubecki 1909b: 346-347).

Innym niezrealizowanym pomysłem Lubeckiego związanym z infrastrukturą transportową była aktywizacja gospodarcza województwa augustowskiego, którą to kwestię poruszał w listach z 4 października 1823 r. i 21 października 1823 r. Książę zwrócił uwagę na zalegające tam płytko pod ziemią złoża rudy żelaza i postulował rozpoczęcie ich zorganizowanej eksploatacji. Aby to umożliwić, należało najpierw wybudować nowe drogi (Drucki-Lubecki 1909a: 328-329, 340, 398-399). Ostatecznie i ten pomysł nie doczekał się realizacji, a przetwórstwo tamtejszej rudy żelaza, ukierunkowane na zaopatrzenie miejscowej ludności, do końca okresu konstytucyjnego nie wyszło poza etap wytopu dymarkowego (Radwan 1963: 147). W „Pamiętniku Górnictwa i Hutnictwa" z 1830 r. czytamy:

W województwach płockim, augustowskim, podlaskim i lubelskim dotychmiast (sic!) żadne zakłady górnicze nie istnieją; a z geognostycznego województw tych położenia, jedynie tylko rudy żelaznej darniowej, węgli brunatnych i torfu spodziewaćby się można. Możnaby jednakże w województwie augustowskim założyć fryszerki i opatrywać je żelazem surowym przez spław z innych części kraju ile że wyborna i obfita ruda żelazna z tej strony Wisły, mniej korzystnym czyni przetapianie piaszczystej rudy darniowej, wydającej kruche i w zimnie rozpryskujące się żelazo (Pusch 1830: 13).

\section{Polityka ekonomiczna Lubeckiego}

W epoce konstytucyjnej przemysł Królestwa Polskiego pozostawał w zalążku, a rzemiosło było słabiej rozwinięte niż w Prusach. Królestwo było krajem rolniczym - 80\% ludności żyło z rolnictwa, a 70\% bogactwa narodowego stanowiła ziemia i płynące z niej dochody. Większość produkcji rolniczej uzyskiwanej przez prywatnych właścicieli ziemskich szła na eksport - 90\% zboża i 70\% produktów zwierzęcych sprzedawano do Anglii za pośrednictwem Prus, a zyski ze sprzedaży produktów rolnych stanowiły $60 \%$ wartości całego eksportu Królestwa. Najważniejszym portem wywozowym był Gdańsk. Wojny napoleońskie wyniszczyły gospodarczo ziemie polskie, spowodowały również wiele innych problemów makroekonomicznych. W początkowym okresie istnienia Królestwa doszło do znacznego pogorszenia warunków funkcjonowania poleskiego rolnictwa: otóż w 1815 r. Anglia, chcąc chronić swój rynek przed zalewem taniej pszenicy z zagranicy, ograniczyła jej import, co dotknęło przede wszystkim 
producentów w Polsce. Ponieważ znacznie skurczył się rynek zbytu, a produkcja nie spadała, ceny zbóż były w Królestwie bardzo niskie (o 20-40\% niższe niż na rynkach Europy Zachodniej), przy czym największy spadek zanotowano w 1824 r. Ziemianie próbowali w związku z tym przestawić się na produkcję roślin, których sprzedaż byłaby bardziej opłacalna, np. ziemniaków, tytoniu, konopi. Ostatecznie jednak rentowność gospodarki rolnej była niska. Bez zapewnienia opłacalności eksportu produktów rolnych (głównie zboża) Królestwu groziła katastrofa ekonomiczna (Pusch 1830: 191192; Strzeszewski 1934: 15).

Ponieważ wolny eksport produktów rolniczych stanowił o „być albo nie być" Królestwa Polskiego, na kongresie wiedeńskim zagwarantowano jedność celną obszarów w granicach Polski przed 1772 r. Sprawę tę uregulował traktat z 3 maja 1815 r., który zabezpieczał tranzyt polskiego zboża Wisłą i niskie cła zapewniające utrzymanie tylko szlaków wodnych. Tymczasem konwencja petersburska z 19 grudnia 1818 r. (akt dopełniający do traktatu z 3 maja 1815 r.) wprowadzała cło tranzytowe oraz otwierała granice Rosji i Królestwa dla wyrobów pruskiego rzemiosła (Smolka 1907b: 365-367).

Fatalnym i niepożądanym dla gospodarki ziem polskich uzupełnieniem tych postanowień był manifest z 20 listopada 1819 r. wprowadzający system wolnohandlowy w Rosji i ukaz z 15 października 1819 r., który włączał Królestwo Polskie do rosyjskiego obszaru celnego. Wejście w życie tego rozporządzenia pociągnęło za sobą ustanowienie na granicy Prus i Królestwa rosyjskich komór celnych, które pobierały cło na towary idące do Rosji tranzytem przez Królestwo. Polsko-rosyjska unia celna obowiązywała od 1 stycznia 1820 r. do 24 marca 1822 r. (Smolka 1907b: 370-371).

Konwencja petersburska z 1818 r. była dla Prus bardzo korzystna, dawała im bowiem możliwość eksportu własnych produktów do Królestwa i Rosji. Tłumiąc z kolei rozwój przemysłu w tych państwach i ograniczając opłacalność eksportu produktów rolniczych z Królestwa, prowadziła do dalszego osłabienia jego gospodarki. Rosja jednostronnie zerwała ten układ 24 marca 1822 r. - wtedy wydany został reskrypt cesarski znoszący unię celną Królestwa i Rosji oraz wprowadzający prohibicyjną taryfę celną na wyroby rzemiosła z Prus. Nowa taryfa została wprowadzona 30 marca 1822 r., a unię celną zniesiono w czerwcu 1822 r. (Smolka 1907b: 371-373).

Ukaz Aleksandra I z 13 sierpnia 1822 r. zniósł cła na produkty przemysłowe wytwarzane w Królestwie Polskim z rodzimych surowców i zarazem wprowadził prohibicyjną taryfę celną na wyroby przemysłowe z Prus. W odpowiedzi na wprowadzone zmiany Prusy ustanowiły zaporowe cła na zboże wwożone czy przechodzące tranzytem przez terytorium państwa pruskiego. Nowa taryfa w ogóle znosiła pojęcie cła tranzytowego (Smolka 1907b: 387). Jak bardzo było to szkodliwe dla gospodarki rolnej Królestwa Kongresowego, pokazuje następujące zestawienie: w 1819 r. wartość eksportu Królestwa wyniosła 13,7 mln zł (w tym wartość wyeksportowanego zboża ok. 9 mln zł). Kwota cła, którą należałoby zapłacić od zboża tej wartości według stawek wprowadzonych 23 kwietnia 1823 r., wyniosłaby 8 mln zł (Bocheński 1966: 
344-345). Był to początek polsko-pruskiej wojny celnej. Rosja, ponieważ Królestwo nie wchodziło w skład jej obszaru celnego, pozostawiła je początkowo własnemu losowi (Drucki-Lubecki 1909b: 392). Drucki-Lubecki musiał użyć wszystkich swoich wpływów w Petersburgu i Warszawie do skutecznego przeciwdziałania gospodarczej katastrofie, do której doprowadziłoby utrzymanie taryfy z 23 kwietnia $1823 \mathrm{r}$.

W tej sytuacji sprawą kluczową dla dalszego istnienia Królestwa Polskiego było stworzenie warunków do rozwoju eksportu produktów rolnych bez pośrednictwa Prus. Drucki-Lubecki chciał przede wszystkim utrzymać korzystne warunki dla eksportu zboża drogą wodną przez Gdańsk. W tym celu należało wywalczyć wolny tranzyt przez Prusy. W liście z 13 sierpnia 1824 r. nazywa Gdańsk „prawdziwym Cerberem u naszych wrót, który nie pozwala ani wejść ani wyjść" (Drucki-Lubecki 1909b: 117-118). Po drugie, Lubecki dążył do wprowadzenia i utrzymania ceł protekcyjnych na wyroby przemysłu pruskiego, aby dostarczyć bodźca do rozwoju rodzimego przemysłu (Drucki-Lubecki 1909a: 383 i nn.).

\section{Kanał Augustowski w korespondencji Lubeckiego}

Jednym z pomysłów Druckiego-Lubeckiego na uniknięcie trudności wynikających z pruskich taryf tranzytowych było znalezienie alternatywnej drogi wodnej łączącej Wisłę z Bałtykiem. Najbardziej oczywistym rozwiązaniem wydawał się kanał łączący przez zespół jezior w okolicach Augustowa - zlewnię Wisły i Niemna. Umożliwiłoby to eksport polskiego zboża i innych towarów bez pośrednictwa Prus, dostarczając tym samym znacznych wpływów skarbowi państwa. Po drugie, budowa kanału współgrała z ideą zacieśniania związków gospodarczych i politycznych Królestwa z Rosją; miała też posłużyć jako narzędzie nacisku w taryfowych negocjacjach z Prusami (Drucki-Lubecki 1909a: 394).

W zachowanej korespondencji Lubeckiego znalazł odbicie proces opracowywania i ostatecznego ustalenia planowanego przebiegu kanału. Jak wynika z listu Grabowskiego do Lubeckiego z 28 maja 1823 roku, car zaakceptował pierwotny pomysł Lubeckiego połączenia Niemna z Dźwiną. Portem morskim kończącym planowany szlak wodny miała być w tym wariancie Ryga (Drucki-Lubecki 1909a: 241). W memoriale o handlu z Prusami z 8 sierpnia 1823 r. zawierającym skrócony opis drogi wodnej łączącej Narew, Niemen i Aa (dziś Musza, Łotwa²) pojawiła się wzmianka o pożądanej reakcji ministrów pruskich na perspektywę bojkotu przez Rosję i Królestwo szlaku wiślanego. W zamyśle Lubeckiego bojkot miał wywrzeć „zbawienny [dla Królestwa] wpływ na ich decyzje, poprzez uświadomienie im możliwych skutków ich błędnych szacunków" (Drucki-Lubecki 1909a: 394; Słownik 1880: 19). Brana pod uwagę jako

\footnotetext{
${ }^{2}$ Chociaż brak w memoriale Lubeckiego dokładniejszych informacji o planowanym przebiegu kanału, to logicznym wydaje się, że szlak żeglowny miał prowadzić poprzez Muszę do Lelupy (również określanej mianem Aa), a dalej do Zatoki Ryskiej.
} 
port morski kończący szlak wodny była także Libawa (dziś Liepāja, Estonia, Drucki-Lubecki 1909a: 391, 392).

Ostatecznie zatwierdzony projekt kanału został zaaprobowany przez cara i wdrożony do realizacji po fiasku negocjacji z Prusami 22 kwietnia 1824 r. Grabowski poinformował Lubeckiego, że Aleksander I przywiązuje wielką wagę do budowy kanału i należy się przygotować na nadzwyczajne wydatki (Drucki-Lubecki 1909b: 61, 71), donosił też w liście z 26 maja 1824 r. o zaaprobowaniu przez imperatora projektu nabrzeży sporządzonego przez Teodora Urbańskiego³ (Drucki-Lubecki 1909b: 76). Już 9 czerwca 1824 r. w Petersburgu zapadła decyzja o przyznaniu wielkiemu księciu Konstantemu 500 tys. złotych z kasy Królestwa na cel budowy kanału, ponieważ tą budową, zgodnie z zamysłem Lubeckiego i wolą cara, miała zająć się armia, inżynierowie wojskowi i żołnierze (Drucki-Lubecki 1909b: 81-82).

Lubecki był zadowolony z takiego obrotu spraw, czemu dał wyraz w liście z 9 lipca 1824 r.:

Zresztą sprawiedliwość zawsze do równowagi szale swej wagi znosi (...) zarządzenia Jego Cesarskiej Mości dotyczące nowych kanałów złagodzą ich ciężar, z drugiej zaś strony dobroć tego Monarchy, równie nieskończona jak Jego potęga, potrafi położyć im kres, gdy Jego mądrość uzna to za stosowne (Drucki-Lubecki 1909b: 99; tłum. za: Górewicz, Orłowski 1971:25).

Podobnie brzmią jego uwagi na temat bezpośredniej komunikacji z Bałtykiem, wyrażone w liście z 13 sierpnia 1824 r.:

[dzięki niej] ziszczą się wszystkie nasze projekty, które dotychczas są tylko wspaniałymi złudzeniami (Drucki-Lubecki 1909b: 118)

Plan zakładał połączenie systemu rzecznego Wisły i Niemna przez Narew i Biebrzę. Kanał Augustowski miał zostać zbudowany przez inżynierów polskich, a Niemen z Windawą miał połączyć poprzez Dubissę KanałWindawski zbudowany przez inżynierów rosyjskich (Drucki-Lubecki 1909b: 61, 70-71, 75,: 81-82; zob. Sumariusz 1961: 314).

Lubeckiego jako ministra skarbu szczególnie interesowały kwestie finansowania budowy Kanału Augustowskiego. W liście z 9 lutego 1825 r. Grabowski relacjonował Lubeckiemu przebieg spotkania, na którym zapoznawał cara z planem kanału i wstępnym kosztorysem. Grabowski szacował, że kanał będzie kosztował 7681 tys. zł. Kwota ta nie obejmowała wszakże kosztów budowy mostów zwodzonych, nabrzeża i portu w Augustowie, odszkodowań dla właścicieli pól, łąk, lasów i młynów, toteż Grabowski przewidywał, że należy się spodziewać wzrostu kosztów do $10 \mathrm{mln}$ zł. Aleksander I sądził, że ta suma przekroczy zdolność budżetu Królestwa i nie obejdzie się bez środków nadzwyczajnych. Polecał również Lubeckiemu porozumieć się z Konstantym, by znaleźć te dodatkowe fundusze „drogą pożyczki lub w inny sposób” (Drucki-Lubecki

3 Urbański Teodor, ur. 4 XI 1792, Wieruszów, zm. 12 II 1850, Warka, inżynier hydrotechnik (Encyklopedia PWN, bd). 
1909b: 176-177). Lubecki odpowiedział w liście z 18 lutego 1825 r., że pożyczka istotnie wydawała mu się najlepszym wyjściem, należało jednak wziąć pod uwagę nie tylko samą wysokość stopy procentowej, ale też planowane zyski z inwestycji; prosił również Grabowskiego o przekazanie jego uwag Mostowskiemu (Drucki-Lubecki 1909b: 183-184).

Jak wspomniano wyżej, budową kanału miało zająć się wojsko. Lubecki zgodził się na to, by projekt, o który zabiegał, zrealizował jego osobisty przeciwnik polityczny Konstanty - ponieważ uważał, że jakakolwiek zwłoka w rozpoczęciu robót jest błędem (Smolka 1907a: 391). Książę-minister zdawał sobie sprawę, że armia dysponowała odpowiednimi ludźmi i strukturami organizacyjnymi do wykonania tego zadania. Praca żołnierzy była tania - wykonanie tego samego zadania kosztowałoby $1 / 3$ tego, ile trzeba byłoby zapłacić cywilnym robotnikom (Górewicz, Orłowski 1971: 56)

Nieco później Lubecki, chociaż budową zajęła się armia i Konstanty, chciał chociaż częściowej i pośredniej kontroli wydatków. Niepokoiło go celowe zawyżanie przez Konstantego kosztów zakupu materiałów budowlanych i innych artykułów potrzebnych do budowy kanału. Lubecki chciał zatwierdzania planów i kosztorysów przez Radę Administracyjną; twierdził również, że zawyżono dziesięciokrotnie cenę kamieni potrzebnych do pokrycia śluz (Drucki-Lubecki 1909b:183). Grabowski obiecał przedstawić ten pomysł carowi, nie mając pewności co do jego reakcji, przejrzał również kosztorysy, jednak Aleksander I do 9 marca 1825 r. nie podjął żadnej decyzji w sprawie zatwierdzania kosztorysów przez Radę Administracyjną (Drucki-Lubecki 1909b: 198).

O starciu Lubeckiego z wielkim księciem mówi list Grabowskiego z 17 lutego 1828 r. Dzień wcześniej Konstanty miał zażądać od Mikołaja I, aby wydać mu ze skarbu Królestwa kwotę niezbędną do ukończenia Kanału Augustowskiego. Lubecki zaprotestował gwałtownie przeciw temu żądaniu (rozmowa Konstantego z carem miała miejsce bez wiedzy i zgody księcia-ministra - w czasie pobytu Konstantego w Petersburgu na początku 1828 r. i zaraz po opuszczeniu miasta przez Lubeckiego). W listach do Grabowskiego z 21 marca 1828 r.i 11 kwietnia 1828 r. Drucki-Lubecki wskazywał, że Komisja Wojny posiada jeszcze na koncie 1220 tys. zł na cel budowy kanału pozostałych z ubiegłego roku, nie ma zatem potrzeby dodatkowego dotowania przedsięwzięcia (Drucki-Lubecki 1909c: 170, 176). Grabowski przedstawił wniosek Lubeckiego carowi, a ten podziękował księciu-ministrowi za „zaciśniętą dłoń [niechętną do dawania pieniędzy ze skarbu] i mądrą głowę". Można zatem przypuszczać, że sprawy potoczyły się po myśli Lubeckiego (Drucki-Lubecki 1909c: 181).

Problem dokończenia budowy Kanału Augustowskiego wraca w korespondencji Lubeckiego w związku ze sprawą planowanego zaciągnięcia przez Rosję pożyczki za granicą na cele inwestycyjne i uzyskania w związku z tym 4200 tys. zł na ukończenie kanału. W październiku 1825 r. Lubecki szacował, że na dokończenie budowy Kanału Augustowskiego potrzeba było jeszcze $9 \mathrm{mln}$ zł (wliczając w to koszty wywłaszczenia). Z listu Grabowskiego z 8 listopada 1826 r. wynika, że kwota dofinansowania 
przeznaczonego na kanał zmniejszyła się do 3500 tys. zł. Wydaje się, że i w tym przypadku Lubecki odniósł częściowy sukces, gdyż car Mikołaj I na początku swego panowania wzbraniał się przed przyznaniem Królestwu jakichkolwiek środków na cele inwestycyjne niezwiązane z rozbudową armii (Drucki-Lubecki 1909b: 336, 341, 345, 347).

Kanał Augustowski stał się elementem nacisku na Prusy, aby zniosły represyjne cło z 10 kwietnia 1823 r., ponieważ jego istnienie czyniło groźbę bojkotu przez Rosję i Królestwo żeglugi Wisłą do Gdańska całkiem realną (Drucki-Lubecki 1909a: 394). Decyzje i rozkazy dla generała Malletskiego w sprawie budowy kanału wywołały zaniepokojenie pruskiego konsula Juliusza Schmidta, który ostrzegał ministra Christiana Bernstorffa w liście z 5 lipca 1824 r., że budowa jest realnym projektem i zagrożeniem dla Prus, a nie tylko zagraniem politycznym, jak wcześniej podejrzewał (Drucki-Lubecki, 1909b: 439). W liście z 13 sierpnia 1824 r. donosił on również ministrowi Christianowi Bernstorffowi:„,gdańscy kupcy piszą do tutejszych korespondentów, że przez ten kanał Gdańsk będzie zrujnowany" (Drucki-Lubecki, 1909b: 441). Lubecki usiłował wpływać na prowadzącego negocjacje z Berlinem w imieniu rządu Królestwa Polskiego barona Pawła Mohrenheima. Namawiał go do usztywnienia stanowiska wobec Prus, roztaczając wizję: „dziesięciu tysięcy ramion oraz kilku milionów [złotych]”, które w dwa lata miały dać Polsce dostęp do Bałtyku przez Rygę (Drucki-Lubecki 1909b: 424). Ostatecznie groźba całkowitego bojkotu szlaku wiślanego i związanych z nim strat wpłynęła na złagodzenie stanowiska Prus w negocjacjach i doprowadziła do przyjęcia nowej taryfy celnej w marcu 1825 roku (Smolka, 1907a: 396) .

Budowa Kanału Augustowskiego trwała od 1824 r. do 1840 r. i pochłonęła (zgodnie z przewidywaniami) ok. $10 \mathrm{mln}$ zł (Smolka 1907b: 401). Inwestycja ta nie przyniosła jednak oczekiwanych korzyści gospodarczych, ponieważ nigdy nie został ukończony Kanał Windawski (którego budowę zarzucono po powstaniu listopadowym), zaś bez otwartego przejścia na Bałtyk Kanał Augustowski pozostał drogą wodną o znaczeniu jedynie regionalnym. Nie oznacza to bynajmniej, że pomysł połączenia Wisły i Niemna z Bałtykiem przez terytorium Rosji całkowicie zarzucono - na przykład w 1849 r. zawiązała się spółka na rzecz budowy linii kolejowej łączącej Jurburg z Libawą, a zatem spełniającej tę samą rolę, którą pełnić miał Kanał Windawski (Kolberg 1849: 616-635).

W szerszej perspektywie budowę Kanału Augustowskiego można jednak uznać za opłacalną, ponieważ zyski uzyskane z handlu zbożem dzięki nowej taryfie celnej nieco przewyższyły koszty budowy. Górowicz podaje za Wolskim, że do 1830 r. koszty budowy kanału wyniosły 1425 303,79 rubli w złocie, natomiast przez 13 lat obowiązywania nowej taryfy celnej, wywalczonej dzięki budowie kanału, Królestwu udało się zaoszczędzić na obniżce ceł 1215923 ruble (Wolski 1849: 79; Górowicz, Orłowski 1971: 58). 


\section{Hutnictwo żelaza w królestwie polskim a kwestia uspławnienia rzeki Kamiennej}

Transport wodny odgrywał również ważną rolę w planach rozwoju hutnictwa żelaza w Królestwie Polskim. Woda dostarczała siły napędowej dla miechów, młotów i walców, była niezbędna w procesie technologicznym produkcji żelaza, umożliwiała ponadto tańszy i szybszy niż lądowy transport surowców, półfabrykatów oraz gotowych wyrobów. Słuszne wydaje się stwierdzenie, że rozwój przemysłu ciężkiego w Kongresówce w I poł. XIX w. uzależniony był całkowicie od wody (Radwan 1963: 41-44).

Górnictwo i hutnictwo w Królestwie Polskim do 1824 r. znajdowało się pod zarządem Komisji Spraw Wewnętrznych i Policji. Komisja zmagała się z permanentnym niedoborem środków na rozbudowę i wznoszenie nowych zakładów. Większość funduszy pochłaniało utrzymanie zakładów już istniejących, przeważnie usytuowanych w lokalizacjach, które nie gwarantowały utrzymania produkcji na wysokim poziomie. Brakowało też wykwalifikowanych urzędników (Gąsiorowska 1922: 197).

Lubecki uważał, że górnictwo i hutnictwo rządowe powinny istnieć po to, by przynosić dochody skarbowi. Królestwo posiadało duże zasoby surowców naturalnych, w związku z czym inwestycje w górnictwie i hutnictwie - zdaniem księcia - mogły i powinny przynosić zyski. To, że tak się nie działo, nie wynikało ze złej woli, a z niewłaściwego wydatkowania środków, braku dokładnych danych i lekceważenia rachunku ekonomicznego (Drucki-Lubecki 1909d: 432-433; Gąsiorowska 1922: 197; Gąsiorowska 1965: 264-265). Aby górnictwo i hutnictwo krajowe stały się źródłem dochodów, Lubecki postulował poddać je szczegółowej analizie. Plan rozwoju tych gałęzi gospodarki miał się oprzeć na wynikach dokładnych obliczeń stanu zasobów naturalnych, możliwości ich wydobycia oraz zdolności przerobowych istniejących zakładów. Plany Lubeckiego z 1824 r. przewidywały niemal trzykrotne zwiększenie produkcji żelaza kutego i surówki w ciągu najbliższych pięciu lat (Radwan 1963: 152-153).

Po dłuższych sporach ze Stanisławem Staszicem Lubecki doprowadził do przejęcia Dyrekcji Górnictwa przez Komisję Rządową Przychodów i Skarbu, co ostatecznie zatwierdził na wniosek namiestnika dekret królewski wydany przez Aleksandra I 14 grudnia 1824 roku (Gąsiorowska 1965: 263-271; Drucki-Lubecki 1909b: 150).

W planach Lubeckiego zwiększenia produkcji żelaza w Królestwie Kongresowym szczególnie ważne były rzeki Bobrzyca, Czarna, Kamienna i Łagownica, ponieważ przeprowadzone pomiary wykazały, że istnieją dobre warunki do ulokowania wzdłuż ich brzegów zakładów przemysłowych. Rzeki Kamienna i Czarna, ze względu na wartki nurt i dużą ilość wody, szczególnie nadawały się na miejsce dla zakładów fryszerskich, zaś obfitość lasów i złóż rudy żelaza na terenach, przez które przepływały Bobrzyca i Łagownica, sugerowała budowę nad ich brzegami wielkich pieców (Radwan 1932: 194-199). 
Kluczową rolę odegrać miała rzeka Kamienna. Według raportu radcy górniczego Fryderyka Lempego z 1 grudnia 1825 r. docelowo wzdłuż jej brzegów miały pracować trzy wielkie piece, trzydzieści cztery fryszerki i siedem par walców (Radwan 1932: 197198, Gąsiorowska 1965: 285). Na rolę tej rzeki w rozwoju hutnictwa żelaza opartego na węglu drzewnym zwracano uwagę, zanim jeszcze Lubecki przejął zarząd nad Dyrekcją Górnictwa. Stanisław Staszic już w 1817 r. planował przekształcić rejon rzeki Kamiennej w swego rodzaju kombinat metalurgiczny. Dążył on do rozlokowania wzdłuż jej biegu zamkniętego cyklu produkcyjnego. Kolejne etapy produkcji wyrobów żelaznych miały odbywać się w zakładach wzdłuż biegu Kamiennej (od dostarczenia surowca przez kopalnie i wielkie piece poprzez przetwarzanie surowca we fryszerniach do wytwarzania gotowych wyrobów w walcowniach i kuźnicach, Bocheński 1985: 98-99; Radwan 1932: 195).

Uspławnienie rzeki Kamiennej od Wąchocka do ujścia do Wisły i budowa kanału żeglugowego miały umożliwić transport surowców i półproduktów pomiędzy kolejnymi etapami produkcji oraz transport gotowych wyrobów do Warszawy i dalej na rynek rosyjski. Dodatkowo kanał miał usprawnić transport marmurów i węgla kamiennego (poszukiwania złóż w okolicach Kunowa i Wierzbnika doprowadziły do odkrycia pokładów węgla kamiennego, podjęto próby jego eksploatacji). Oprócz węgla niedaleko Kamiennej wydobywano również rudę żelaza (Bocheński 1985: 98-99; Gąsiorowska 1922: 543; Gąsiorowska 1965: 287; Radwan 1963: 151-152).

Car Aleksander I zainteresował się projektem uspławnienia rzeki. W odezwie ministra sekretarza stanu z 30 sierpnia 1823 r. zadeklarował gotowość częściowego sfinansowania robót związanych z oczyszczeniem i regulacją rzeki Kamiennej (Sumariusz 1961: 404). W odezwie stwierdzał:

zważywszy, że stan skarbu nie pozwala rządowi przedsięwziąć w teraźniejszej chwili tak użytecznych robót, raczył oświadczyć w łaskawej swej troskliwości dla dobra Królestwa Polskiego, że skłonnym jest przyczynić się z własnych funduszów do kosztów, których by spławienie rzeki pomienionej wymagało. Namiestnik przeto wezwany zostaje do rozkazania, aby ułożono plan i anszlagi robót, jakie w tym celu przedsięwzięte być mają i do przedstawienia takowych pod zatwierdzenie Npana (Gąsiorowska 1965: 467, aneks nr 12)

Podczas posiedzenia Rady Administracyjnej 8 kwietnia 1823 r. w odezwie ministra sekretarza stanu imperator ponownie nakazywał natychmiastowe rozpoczęcie prac przy budowie kanału żeglownego zasilanego wodą z Kamiennej i przebiegającego wzdłuż koryta tej rzeki (Sumariusz 196: 312). Po powodzi, która wiosną 1824 r. wyrządziła poważne szkody w zakładach przemysłowych położonych wzdłuż Kamiennej, przystąpiono do odbudowy zniszczeń oraz wykonano dziewięć nowych przekopów między Starachowicami a Ostrowcem. Kosztowało to 113 tys. zł, nie licząc obwałowań (Bocheński 1985: 98-99).

Od 10 września do 5 października 1824 r. Drucki-Lubecki dokonywał objazdu zakładów przemysłowych Królestwa. W czasie inspekcji przejrzał dokumentację i dokonawszy 
wizytacji miejsca robót na rzece Kamiennej zdecydował o modyfikacji oryginalnych planów Staszica (Gąsiorowska 1965: 269; Szczepański 2008: 163).

W listach z 10 i 17 listopada 1824 r. Lubecki tłumaczył carowi za pośrednictwem ministra sekretarza stanu, że jego zdaniem priorytetem nie jest żegluga na Kamiennej, lecz rozwój przemysłu. Wskazywał przy tym na nieopłacalność planowanego przez Staszica transportu marmurów i innych surowców występujących w dogodniejszych lokalizacjach. Co więcej, Kamienna raz była - jak zauważał - „rwącym potokiem”, a raz „słabym strumykiem”. Przez większą część roku w rzece było zbyt mało wody, aby jednocześnie zasilać kanał i dostarczać energii zakładom przemysłowym. Lubecki uważał, że w takiej sytuacji ważniejsze od uspławniania było zapewnienie stałego działania zakładów. Aby w pełni zaspokoić potrzeby przemysłu, należało jego zdaniem przyspieszyć prace nad konstrukcją rezerwuaru wody i przekopu „w miejscu bagniska otoczonego przez wzgórza", tj. w okolicach Kunowa i Starej Rudy. Wykonanie tych prac miało czterokrotnie zwiększyć możliwości produkcyjne zakładów nad Kamienną. Dopiero po wykonaniu tych robót można było planować budowę kanału żeglugowego (Drucki-Lubecki 1909b: 124-130, 134-135; Radwan 1963: 43).

Środki już zgromadzone na prace regulacyjne należało zdaniem księcia-ministra zainwestować w fabryki, ponieważ i tak pieniędzy było za mało, by osiągnąć pierwotny cel. Lubecki uważał, że pieniądze wydane na prace, których nie można by ukończyć, zostałyby zmarnowane. Zaoszczędzone środki Lubecki wolał przeznaczyć na rozwój przemysłu, co byłoby o tyle korzystne, że nie obciążałoby dodatkowo skarbu (Drucki-Lubecki 1909b:124-130; zob. Gąsiorowska 1965: 277).

W liście z 29 lipca 1825 r. Lubecki powrócił do kwestii rzeki Kamiennej, stwierdzając, że uspławnienie tej rzeki byłoby konieczne dopiero w momencie, gdyby produkcja żelaza wzrosła do 300 tys. cetnarów i gdyby podwoiła się produkcja cynku w Olkuszu ${ }^{4}$ (Drucki-Lubecki 1909b: 209-213). Z kolei w liście z 18 sierpnia Lubecki informował, że roboty przy regulacji Kamiennej powierzył spółce Piotr Steinkeller - Konstanty Wolicki, a wykonać je miał inżynier i wynalazca francuski Philippe Girard, którego w tymże liście nazywał „prawdziwym geniuszem w wynajdywaniu, udoskonalaniu i usprawnianiu" (Drucki-Lubecki 1909b: 213-216; Górewicz, Orłowski 1971: 125).

Koszt regulacji rzeki Kamiennej w latach 1825-1829 wyniósł w kolejnych latach: 116666 zł (1825), 594119 zł (1826), 959886 zł (1827) i 504119 (1828). Po 1831 r. prace te kontynuowano dopóty, dopóki rozwijał się kompleks zakładów przemysłowych w Starachowicach. W zmieniającej się sytuacji gospodarczej (m.in. doprowadzenie linii kolejowej do Starachowic w 1885 r., przestawienie pieców na opalanie węglem kamiennym zamiast węglem drzewnym czy nowe procesy technologiczne oczyszczania surówki) pomysł kanału żeglownego został zarzucony. Rzeka Kamienna dostarczała energii i wody niezbędnej w procesach technologicznych tamtejszych fabryk, nie

\footnotetext{
${ }^{4}$ Niestety, Lubecki nie sprecyzował, czy chodziło mu o 300 tys. cetnarów surówki czy gotowego żelaza (1 cetnar to ok. $64,8 \mathrm{~kg}$ ).
} 
wykorzystywano jej natomiast do transportu produktów - ten odbywał się bitym traktem prowadzącym do Sandomierza. Kapryśna rzeka nie dała się całkowicie ujarzmić, a katastrofalne w skutkach powodzie powtarzały się w kolejnych latach. Przykładowo w 1903 r. przepływ wód zwiększył się 350 razy, co spowodowało uszkodzenie grobli, całkowite zniszczenie zakładów w Brodach i unieruchomienie walcowni w Nietulisku. Poniesione straty niewątpliwie przyczyniły się do podjęcia decyzji o zamknięciu kompleksu w Starachowicach w 1907 roku (Radwan 1963: 164-171).

\section{Transport soli w planach gospodarczych Lubeckiego}

Rząd Królestwa Polskiego, podobnie jak w okresie Księstwa Warszawskiego, miał monopol na hurtową sprzedaż soli. Stanowiło to dla państwa znaczące źródło dochodów. Skarb, tak jak w latach poprzednich, zawierał kontrakty z prywatnymi spółkami na transport soli importowanej i krajowej z magazynów rządowych zlokalizowanych wzdłuż największych rzek do ponad czterdziestu składów regionalnych. Transport soli odbywał się przeważnie drogą wodną (Kołodziejczyk 1963: 27-28, 38, 60).

Lubecki poświęcał problemowi soli wiele uwagi zwłaszcza w początkowym okresie sprawowania urzędu ministra skarbu. Temat monopolu solnego poruszała większość jego listów do Sobolewskiego z lat 1821-1823. Inicjatywą Lubeckiego było odzyskanie administrowania hurtową sprzedażą soli dla rządu oraz pozostawienie dzierżawienia administracji transportu prywatnym podmiotom (zamiast dzierżawienia całości monopolu solnego). Dzięki temu udało mu się istotnie obniżyć koszty i zwiększyć zyski skarbu (zob. Drucki-Lubecki 1909a: 1, 13, 16-18, 20, 29-30, 47, 135, 146-149; Kołodziejczyk 1963: 60-61). Dzięki zabiegom Lubeckiego znacznie zwiększyły się dochody skarbu z handlu solą (w latach 1816-1821 dochód wyniósł 5-5,5 mln zł rocznie, od 1821 r. było to już ok. 13-14 mln zł rocznie). Zmiana sposobu dzierżawy monopolu solnego nie wpłynęła w żaden sposób na cenę soli w handlu detalicznym, która wciąż pozostawała niezwykle wysoka (Kołodziejczyk 1963: 29, 38).

W związku z organizacją transportu soli książę-minister może uchodzić za prekursora polskiej żeglugi parowej na Wiśle. Realizacja tego projektu przypadła Konstantemu Wolickiemu. Jego rola nie ograniczała się do kupowania i sprowadzania soli oraz maszyn z zagranicy. W porozumieniu z Lubeckim odbył on szereg podróży zagranicznych, których celem była działalność określana dziś mianem szpiegostwa przemysłowego (Drucki-Lubecki 1909b: 209; zob. Woźniak 2000: 18-23).

W marcu 1825 r. Lubecki z upoważnienia Rady Administracyjnej zawarł z kontrakt z Piotrem Steinkellerem i wspomnianym Konstantym Wolickim. Pisał o tym do Grabowskiego w liście z 5 sierpnia 1825 r. (Drucki-Lubecki 1909b: 213-218). Według umowy z 17 sierpnia 1825 r. kontrahenci złożyli depozyt wysokości 400 tys. zł i zobowiązali się do „transportu soli rządowej niemniej płodów i wyrobów górniczych” przez okres dziesięciu lat (Radziszewski, Kindelski 1904: 23). W tym celu przedsiębiorcy mieli w ciągu dwóch lat od początku obowiązywania umowy, tj. od 1 kwietnia 1826 r., zbudować „na 
własne risco (sic!) 100 płaskodennych statków żaglowych". Miały one być zwodowane w warsztatach w Rybakach k. Wyszogrodu, które spółka specjalnie wydzierżawiła od rządu. Oprócz tego kontrahenci zobowiązali się do zbudowania statku parowego do ciągnięcia pustych łodzi w górę rzeki (Radziszewski, Kindelski 1904: 23; Kołodziejczyk 1963: 28; Drucki- Lubecki 1909b: 213-216).

Zgodnie z kontraktem obowiązek zorganizowania floty spoczął na barkach Konstantego Wolickiego (Kołodziejczyk 1963:41-43). Prawdopodobnie za kwotę 13 tys. dukatów zakupił on w Liverpoolu statek parowy „Victory” (Lipiński 1883: 164-165). Była to jednostka przeznaczona do żeglugi śródlądowej, płaskodenna, bocznokołowa, a jej silnik miał prawdopodobnie moc $60 \mathrm{KM}$. Niestety, statek ten miał uszkodzony kocioł i nie tyle więc przypłynął, ile został przyholowany do Gdańska w czerwcu 1827 r. Rosyjski konsul generalny w Gdańsku, Anton Makarowicz, zorganizował huczną imprezę powitalną jednostki z udziałem najważniejszych osób w mieście ${ }^{5}$ (Gazeta 1827: 797, za: Arkuszewski 1973: 28, 30-31).

W sierpniu 1828 r. statek Wolickiego płynął o własnych siłach w górę Wisły do Warszawy. Ujawniła się wówczas jego największa wada - zbyt duże zanurzenie. Utknął koło wsi Potok niedaleko Bielan i stał tam od 11 do 31 sierpnia 1828 r. Aby zminimalizować straty, Wolicki zdecydował się urządzić na pokładzie chwilowo bezużytecznej jednostki bufet i udostępnić ją do zwiedzania. Prasa warszawska informowała, że koszt zwiedzania statku parowego wynosił jeden złoty od dorosłego i piętnaście groszy „od dziecięcia", zaś pieniądze przeznaczano na dofinansowanie Towarzystwa Zupy Rumfordzkiej (Kurier 1828a: 907; Kurier 1828b: 959; Kurier 1828c: 991).

Statek ze względu na zbyt duże zanurzenie nie spełnił pokładanych w nim nadziei. Służył jako spacerowiec, a w czasie Powstania Listopadowego wraz z resztą floty Wolickiego prawdopodobnie został zniszczony (Arkuszewski 1973: 32-33).

\section{Uwagi końcowe}

Książę-minister Drucki-Lubecki przywiązywał dużą wagę do kwestii żeglugi śródlądowej, której wyznaczał istotne miejsce w swoich planach rozwoju przemysłu i górnictwa w Królestwie Polskim. Transport wodny odgrywał również kluczową rolę w eksporcie zboża, stanowiącym podstawę gospodarki Królestwa Kongresowego. O uwolnienie handlu wiślanego krępowanego przez restrykcyjne taryfy pruskie Lubecki przeprowadził skuteczną walkę. Zrozumienia roli transportu wodnego dowodzi fakt, że książę Drucki-Lubecki poświęcał mu stosunkowo dużo miejsca w swoich listach adresowanych do carów Rosji, w których poruszał jedynie najważniejsze dla państwa kwestie. Z racji specyfiki korespondencji Lubeckiego funkcjonującej na styku sfery prywatnej i publicznej, stanowiącej poufny kanał komunikacji z carem poza kontrolą (co nie

\footnotetext{
${ }^{5}$ Arkuszewski podaje również informacje o drugiej jednostce sprowadzonej przez Wolickiego - statku morskim Książę Xawery, zbudowanym w Yarmouth. Jego dalsze losy nie są jasne, jednak z pewnością nie pływał po Wiśle.
} 
znaczy, że bez wglądu) namiestnika Zajączka, senatora Nowosilcowa i wielkiego księcia Konstantego, ma to jeszcze głębszą wymowę.

\section{Literatura}

Arkuszewski W., 1973, Wiślane statki pasażerskie XIX i XX W., Gdańsk: Ossolineum.

Bocheński A., 1966, Wędrówki po dziejach przemysłu polskiego, t. 1, Warszawa: Pax.

Bocheński A., 1985, Niezwykłe dzieje przemysłu polskiego, Warszawa: Krajowa Agencja Wydawnicza. Drucki-Lubecki F.K., 1909a, Korespondencja Lubeckiego z ministrami sekretarzami stanu lgnacym Sobolewskim i Stefanem Grabowskim, t. 1, 1821-1823, oprac. S. Smolka, Kraków: Akademia Umiejętności. Drucki-Lubecki F.K., 1909b, Korespondencja Lubeckiego z ministrami sekretarzami stanu lgnacym Sobolewskim i Stefanem Grabowskim, t. 2, 1824-1826; oprac. S. Smolka, Kraków: Akademia Umiejętności.

Drucki-Lubecki F.K., 1909c, Korespondencja Lubeckiego z ministrami sekretarzami stanu lgnacym Sobolewskim i Stefanem Grabowskim, t. 3, 1827-1830; oprac. S. Smolka, Kraków: Akademia Umiejętności.

Drucki-Lubecki F.K., 1909d, Korespondencja Lubeckiego z ministrami sekretarzami stanu lgnacym Sobolewskim i Stefanem Grabowskim, t. 4, Dodatki, uzupełnienia, indeksy; oprac. S. Smolka, Kraków: Akademia Umiejętności.

Encyklopedia PWN, bd, Encyklopedia PWN online [dostępne elektronicznie], Warszawa: Państwowe Wydawnictwo Naukowe, http://encyklopedia.pwn.pl/szukaj/Urba\%C5\%84ski-Teodor.html [dostęp: 18.02.2015].

"Gazeta Krakowska", 1927, nr 58, 22.07.1827 r.

Gąsiorowska N., 1922, Górnictwo i hutnictwo w Królestwie Polskim 1815-1830, Warszawa: Gebethner i Wolff.

Gąsiorowska N., 1965, Z dziejów przemysłu w Królestwie Polskim 1815-1840, Warszawa: Państwowe Wydawnictwo Naukowe.

Górewicz J., Orłowski B., 1971, Kanał Augustowski, jego dzieje i przyszłość, Warszawa: Wiedza Powszechna.

Jezierski A., S. Zawadzki S., 1966, Dwa wieki przemysłu w Polsce: zarys dziejów, Warszawa: Wiedza Powszechna.

Kolberg W., 1849, Droga żelazna z Libawy do Jurburga „Biblioteka Warszawska: pismo poświęcone naukom, sztukom i przemysłowi", t. 3.

Kołodziejczyk R., 1963, Piotr Steinkeller, kupiec i przemysłowiec 1799-1854, Warszawa: Państwowe Wydawnictwo Naukowe.

„Kurier Warszawski”, 1928a, nr 215, 11.08.1828 r.

„Kurier Warszawski", 1928b, nr 227, 24.08.1828 r.

"Kurier Warszawski", 1928c, nr 235, 1.09.1828, r.

Lipiński T., 1883, Zapiski z lat 1825-1831, do druku przygotował i przypiskami objaśnił K. Bartoszewicz, Kraków: K. Bartoszewicz.

Pusch J. R., 1830, Historyczno-statystyczny obraz stanu i produkcji górnictwa i hutnictwa polskiego, „Pamiętnik Górnictwa i Hutnictwa”, t. 1, nr 1.

Radwan M., 1932, Dolina rzeki Kamiennej w programie Staszica i Drucko-Lubeckiego (sic), „Ziemia”, t. 17, R. 22, nr 7.

Radwan M., 1963, Rudy, kuźnice i hutyżelaza w Polsce, Warszawa:Wydawnictwa Naukowo-Techniczne. 
Radziszewski H., Kindelski J., 1904, Piotr Steinkeller - dwie monografie, Warszawa: Czciciele pamięci Steinkellera.

Słownik, 1880, Słownik geograficzny Królestwa Polskiego i innych krajów słowiańskich, red. B. Chlebowski, F. Sulmierski, W. Walewski, t. 1, Warszawa: Druk „Wieku”.

Smolka S., 1907a, Polityka Lubeckiego przed Powstaniem Listopadowym, t. 1, Kraków: Akademia Umiejętności.

Smolka S., 1907b, Polityka Lubeckiego przed Powstaniem Listopadowym, t. 2, Kraków: Akademia Umiejętności.

Strzeszewski C., 1934, Kryzys rolniczy na ziemiach Księstwa Warszawskiego i Królestwa Kongresowego 1807-1830, Lublin: [wydawca nieznany].

Strzeszewski C., 1937, Handel zagraniczny Królestwa Kongresowego 1815-1830, Lublin: [wydawca nieznany]. Sumariusz,1961, Sumariusz protokołów Rady Administracyjnej Królestwa Polskiego, 18151867, Cz. 1, 1815-1830. T. 3, Sekcje: V-VI, VII, oprac. K. Konarski i in., Warszawa: Państwowe Wydawnictwo Naukowe.

Szczepański J., 2008, Ksiq̨żę Ksawery Drucki-Lubecki (1778-1846), Warszawa:Wydawnictwo DiG.

Wolski L., 1849, Rys hydrografii Królestwa Polskiego z wiadomością o spławach (ciąg dalszy), „Biblioteka Warszawska: pismo poświęcone naukom, sztukom i przemysłowi", t. 3.

Woźniak K., 2000, Europejskie podróże polskich industrialistów. O znaczeniu "efektu demonstracji" dla uprzemysłowienia Królestwa Polskiego [w:] Europa w krzywym zwierciadle XIX i XX wieku, red. A. Barszczewska-Krupa, Łódź: Wydawnictwo Uniwersytetu Łódzkiego.

Zdzitowiecki J., 1948, Xiq̨żę-minister Franciszek Xawery Drucki-Lubecki 1778-1846, Warszawa: S. Arct. 